Dicle Tıp Dergisi / Dicle Med J (2018) 45 (3) : 229-235

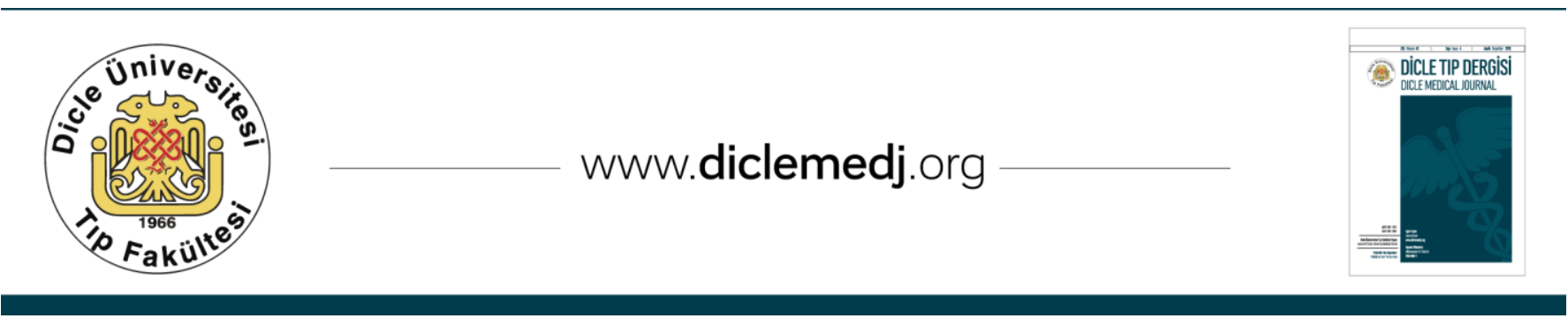

Original Article / Özgün Araştırma

\title{
Chronic Cough: A neglected area in pediatric clinical practice
}

\author{
Ali Özdemir'1, Özlem Yılmaz² \\ 1 Mersin City Training \& Research Hospital, Pediatric Pulmonology Section, Mersin, Turkey ORCID: 0000-0002-9574-7466 \\ 2 Mersin City Training \& Research Hospital, Pediatric Allergy and Immunology Section, Mersin, Turkey ORCID: 0000-0003-2971-283x
}

Received: 12.10.2017; Revised: 26.04.2018; Accepted: 02.05.2018

\begin{abstract}
Objective: Cough is one of the most common but usually neglected complaint in pediatric clinical practice. We aimed to explore the knowledge, attitude and clinical practice among general pediatricians on chronic cough management. Methods: Data were prepared as questionnaires that had been developed by cough guidelines in the literature.

Results: Among 109 general pediatricians, a total of $88(80,7 \%)$ participated into the study; $43.2 \%$ were female and the mean age was $42.01 \pm 7.89$ yrs. The response for the definition of chronic cough ranged from 2 weeks to 6 months. Of the participants, $45.4 \%$ stated that they frequently evaluated children with chronic cough. The majority (79.5\%) sought consultation from one to four discrete specialties. The most frequently ordered two tests were chest radiography (88.6\%) and complete blood count (30.7\%). The majority of pediatricians prescribed antibiotics $(95.5 \%)$, antitussives (67.0\%), expectorants (77.3\%), anti-histamines (62.5\%) and empiric anti-reflux medications $(69.3 \%)$ to children with chronic cough. Most commonly prescribed antibiotic was macrolides (95.5\%). Among pediatricians, only $12.5 \%$ questioned passive smoking exposure and rarely advised professional counseling against smoking to parents (55.6\%).Overall, $66.0 \%$ of pediatricians agreed that they did not feel fully satisfied in the management of chronic cough in children. All supported the preparation of a national guideline and were willing for postgraduate education on chronic cough management.

Conclusions: This study emphasizes the pediatricians' lack of knowledge on chronic cough management in children. Education is crucially important on chronic cough management among general pediatricians which possibly decrease the differences in personal practice.
\end{abstract}

Keywords: Children, chronic cough, management

DOI: $10.5798 /$ dicletip. 457227

Yazışma Adresi / Correspondence: Ali Özdemir, Pediatric Pulmonology Section Department of Pediatrics, Mersin City Training \& Research Hospital, Mersin Türkiye e-mail: aliozdemir2924@yahoo.com 


\section{Kronik Öksürük: Çocuk Hastalıkları Klinik Pratiğinde İhmal Edilen Alan}

$\ddot{0} \mathbf{z}$

Giriş: Çocuk hastalıkları pratiğinde öksürük en sık ve aynı zamanda en az irdelenen şikayettir. Çalışmamızda, kronik öksürük yönetimi hakkında genel pediatristlerin bilgi, tavır ve klinik yaklaşımlarını araştırmayı amaçladık.

Yöntemler: Veri bilgileri literatürde öksürük rehberlerinden geliştirilen anket ile sağlanmıștır.

Bulgular: Çalışmamıza Mersin bölgemizde 109 genel pediatri hekiminden 88'i $(\% 80,7)$ katılmıș, bunlardan \%43,2'si kadın ve yaş ortalaması $42.01 \pm 7.89$ yıldır. Kronik öksürügün tanımına verilen yanıtlar 2 hafta ile 6 ay arasında değişkenlik göstermiştir. Çalışmaya katılanların \%45,4 kronik öksürük şikayeti olan çocuklarla sık karşılaştıklarını belirtmişlerdir. Çoğunlukla $(\% 79,5) 1$ ile 4 arası diğer branşlardan (çocuk allerji, çocuk göğüs hastalıkları ve çocuk gastroenteroloji) konsültasyon ile yardım talep edilmiştir. En sık istenen testler akciğer radyografisi $(\% 88,6)$ ve tam kan sayımıdır (\%30,7). Kronik öksürük tedavisinde çocuk hekimlerinin çoğunluğu sıklıkla antibiyotikler $(\% 95,5)$, öksürük kesiciler $(\% 67,0)$, ekspektoranlar $(\% 77,3)$, antihistaminikler $(\% 62,5)$ ve ampirik antireflü $(\% 69,3)$ tedavisi önermişlerdir. En sık yazılan antibiyotik makrolidlerdir $(\% 95,5)$. Pasif sigara maruziyetini sadece \%12,5 çocuk hekimi sorgulamış ve sigara içen ebeveynlere nadiren profesyonel yardım almaları önerisinde bulunmuştur $(\% 55,4)$. Çocuk hekimlerinin çoğunluğu $(\% 66,0)$ kronik öksürük yönetiminde yeterli olmadıklarını düşünmüşlerdir. Tüm hekimler kronik öksürükle ilgili ulusal rehbere ihtiyaç olduğunu ve bu konuda mezuniyet sonrası eğitime katılmak istediklerini belirtmişlerdir.

Sonuçlar:Çalıșmamıza katılan çocuk hekimlerinin kronik öksürük yönetimi ile ilgili bilgi eksiklikleri vurgulanmışlardır. Genel çocuk hekimliğinde kişisel klinik farklılıkları azaltmak için kronik öksürük yönetimi eğitimi gereklidir.

Anahtar Kelimeler: Çocuklar, kronik öksürük, yönetim

\section{INTRODUCTION}

Cough is one of the most common complaint for health care units ${ }^{1,2}$. Cough persistance for a couple weeks is probably terrifying to parents and so that, they often seek multiple discrete speciality visits ${ }^{1,3-5}$.

Parents who seek help for their coughing children are almost routine in pediatric outpatient practice. It is commonly challenging for general pediatricians to manage both the child and the anxious family. This is especially difficult in a busy clinic where there is little time to spend in the diagnoses with an anxious parents.In such a complicated environment, pediatricians should perform an accurate clinical management, be able to identify clues suggestive of specific disorders and also tend to avoid unnecessary further investigations.

The aim of the present study was to explore the knowledge of general pediatricians working in the health care centers about chronic cough management in children, and determine their attitudes and clinical practices in this context.

\section{METHODS}

\section{Study design}

This study was planned as a cross sectional and descriptive design, and carried out between September and December in 2015. The general pediatricians practicing at the health care centers in Mersin province were given information and invited to participate in a questionnaire-based study. Those who agreed to participate were included in the study.

\section{Survey}

Data were collected by means of a questionnaire that had been developed in the cough guidelines in the literature ${ }^{6,7}$. The questionnaire was e-mailed to the participants or delivered as a form and filled out in a selfadministered format. The participants were informed that the questionnaire would be 
implemented with full confidentiality and anonymity. The questionnaire consisted of questions regarding the demographic characteristics of the pediatrician, the pediatrician's knowledge, attitude and practice in the management of chronic cough in children. The questionnaire also explored pediatrician's awareness of chronic cough guidelines in children and educational support on this topic. The current study was approved by the Mersin University Ethical Board Committee.

\section{Statistical Analysis}

Statistical analysis was performed using the Statistical Package for the Social Sciences (SPSS) version 17.0 software statistical package program (SPSS Inc., Chicago, IL). Qualitative and quantitative variables are shown as number of cases with percentages and mean standard deviation (SD).

\section{RESULTS}

A total of 109 pediatricians were contacted in Mersin province, and 88 (80.7\%) of them agreed to participate in the study. Overall, $43.2 \%$ were females $(n=38)$. The mean age of the participants was $42.01 \pm 7.89$ years. Time interval since residency ranged from 2 to 33 years.Among pediatricians, 50\% worked at private hospitals and 50\% worked at state hospitals (Table 1).

When questioned about the definition of chronic cough, the answers were variable among each participant [>2 weeks: 19.3\% $(\mathrm{n}=17),>3$ weeks: 29.5\% $(\mathrm{n}=26),>4$ weeks: $43.2 \%(\mathrm{n}=38),>3$ months: $4.5 \%(\mathrm{n}=4),>6$ months: $3.4 \%(n=3)]$.

When questioned about the frequency of children with chronic cough in their clinical practice, $45.4 \% \quad(n=40)$ of the pediatricians explained that they frequently evaluated children with chronic cough, $43.2 \%(n=38)$ of them stated that they sometimes evaluated those children in their clinical practice.
Table 1.Demographic characteristics of the pediatricians.

\begin{tabular}{|l|c|}
\hline & n (\%) \\
\hline Age & $42(47.7)$ \\
\hline $30-40$ years & $32(36.4)$ \\
\hline $41-50$ years & $14(15.9)$ \\
\hline 51-61 years & \\
\hline Gender & $50(56.8)$ \\
\hline Male & $38(43.2)$ \\
\hline Female & \\
\hline Employment & $50(50)$ \\
\hline State hospital & $50(50)$ \\
\hline Private hospital & $16(18.2)$ \\
\hline Time since residency & $9(10.2)$ \\
\hline 0-5 years & $32(36.4)$ \\
\hline 6-10 years & $17.3)$ \\
\hline $11-15$ years & \\
\hline $16-20$ years & \\
\hline$>21$ years & \\
\hline
\end{tabular}

The majority ( $n=70,79.5 \%)$ described that they consulted children with chronic cough to subspecialty or other specialty clinics (range one to four discrete specialties). The most frequently consulted clinics were either pediatric pulmonology and pediatric allergy $(55.6 \%)$ or pediatric pulmonology, pediatric allergy and pediatric gastroenterology (11.3\%). When the pediatricians were asked the most common initial investigation they obtained from children with chronic cough, these were chest radiography $88.6 \%(n=78)$, complete blood count and/or C-reactive protein 30.7\% $(\mathrm{n}=27)$, total IgE $28.4 \% \quad(\mathrm{n}=25)$, sinus radiography $10.2 \%(n=9)$, PPD $10.2 \%(n=9)$, spirometry $6.8 \%(n=6)$, throat culture $2.3 \%$ $(n=2)$, sputum for culture $2.3 \%(n=2)$, reflux scintigraphy $2.3 \%(\mathrm{n}=2)$.

Overall, $95.5 \%$ of the pediatricians expressed that they prescribed antibiotics to children with chronic cough. When questioned about the antibiotic group they preferred, the most 
common two prescribed antibiotics were macrolides (95.5\%, $\mathrm{n}=84$ ) and amoxicillin clavulanate $(39.7 \%, \quad n=35)$. The other prescribed antibiotic groups were second generation cephalosporins (18.2\%, $n=18)$, amoxicillin (15.9\%, $\mathrm{n}=14)$ and third generation cephalosporins $(11.3 \%, \mathrm{n}=10)$.

The percentage of pediatricians who could advise antitussive, expectorant and antihistamine prescriptions to children with chronic cough were $12.5 \%, 30.7 \%$ and $21.6 \%$, respectively. Furthermore, the pediatricians who stated they had prescribed antitussives, expectorants and anti-histamines to children with chronic cough were $67.0 \%(n=59), 77.3 \%$ $(n=68)$ and $62.5 \%(n=55)$, respectively. Sixty one $(69.3 \%)$ pediatricians stated that they had prescribed empiric anti-reflux medications to children with chronic cough when no causative factor was identified. Overall, the pediatricians prescribed oral corticosteroids $18.1 \%(n=16)$ and inhaled corticosteroids 76.1\% $(n=67)$ to children with chronic cough (Table 2).

Table 2.Pediatricians knowledge and practices about chronic cough management in children.

\begin{tabular}{|l|c|c|c|c|}
\hline Item & $\begin{array}{c}\text { Never } \\
\mathrm{n}(\%)\end{array}$ & $\begin{array}{c}\text { Rarely } \\
\mathrm{n}(\%)\end{array}$ & $\begin{array}{c}\text { Sometimes } \\
\mathrm{n}(\%)\end{array}$ & $\begin{array}{c}\text { Frequently } \\
\mathrm{n}(\%)\end{array}$ \\
\hline How often do you prescribe antibiotics to children with chronic cough? & $4(4.5)$ & $\begin{array}{c}40 \\
(45.5)\end{array}$ & $38(43.2)$ & $6(6.8)$ \\
\hline $\begin{array}{l}\text { How often do you prescribe antitussives to children with chronic } \\
\text { cough? }\end{array}$ & $29(33)$ & $\begin{array}{c}33 \\
(37.5)\end{array}$ & $18(20.5)$ & $8(9.0)$ \\
\hline $\begin{array}{l}\text { How often do you prescribe expectorants to children with chronic } \\
\text { cough? }\end{array}$ & $20(22.7)$ & $\begin{array}{c}30 \\
(36.4)\end{array}$ & $33(35.2)$ & $5(5.7)$ \\
\hline $\begin{array}{l}\text { How often do you prescribe oral steroids to children with chronic } \\
\text { cough? }\end{array}$ & $72(81.8)$ & $\begin{array}{c}12 \\
(13.6)\end{array}$ & $4(4.6)$ & - \\
\hline $\begin{array}{l}\text { How often do you prescribe inhaler corticosteroids to children with } \\
\text { chronic cough? }\end{array}$ & $21(23.9)$ & $\begin{array}{c}23 \\
(26.1)\end{array}$ & $42(47.7)$ & $2(2.3)$ \\
\hline $\begin{array}{l}\text { How often do you prescribe antihistamines to children with chronic } \\
\text { cough? }\end{array}$ & $33(37.5)$ & $\begin{array}{c}31 \\
(35.2)\end{array}$ & $17(19.3)$ & $7(8.0)$ \\
\hline $\begin{array}{l}\text { How often do you prescribe empiric anti-reflux medications to } \\
\text { children with chronic cough when no causative factor was identified? }\end{array}$ & $27(30.7)$ & $\begin{array}{c}28 \\
(31.8)\end{array}$ & $31(35.2)$ & $2(2.3)$ \\
\hline $\begin{array}{l}\text { Do you ever think a diagnosis of psychogenic cough in children with } \\
\text { chronic cough? }\end{array}$ & $19(21.6)$ & $\begin{array}{c}31 \\
(35.2)\end{array}$ & $36(40.9)$ & $2(2.3)$ \\
\hline \begin{tabular}{l} 
Do you ever question passive smoking in children with chronic cough? \\
\hline
\end{tabular} & - & $\begin{array}{c}11 \\
(12.5)\end{array}$ & $68(77.3)$ & $9(10.3)$ \\
\hline
\end{tabular}

All the pediatricians believed in parental smoking cessation to be useful for the treatment and prevention of chronic cough in children. However, $12.5 \% \quad(n=11)$ explained that they rarely questioned environmental tobacco smoke exposure in children with chronic cough. Additionally, 55.6\% $(n=49)$ of the pediatricians expressed that they even rarely advised parents professional counseling about smoking cessation (Table 2).

Among the participants, $66 \%$ explained that they did not satisfy with their approach in the management of chronic cough in children. Only $56.8 \%$ stated that they were aware of American
Academy of Chest Physicians (AACP) and British Thoracic Society (BTS) guidelines about the management of cough in children. All of the participants pointed out that the development of a national cough guideline would be helpful and support a session about chronic cough management at national congresses (Table 3).

\section{DISCUSSION}

The present study showed that general pediatricians frequently evaluated children with chronic cough in their clinical practice and consulted nearly two thirds of those children to discrete specialties.The majority of 
pediatricians stated that they prescribed antibiotics, especially macrolides, to children with chronic cough. Although most of them knew that antitussives and expectorants should not be used in children with chronic cough, most of them prescribed those over-thecounter medicines at some time in their clinical practice.

Table 3.Pediatricians attitudes about chronic cough.

\begin{tabular}{|l|c|c|c|}
\hline Item & $\begin{array}{c}\text { Yes } \\
\mathbf{n}(\boldsymbol{\%})\end{array}$ & $\begin{array}{c}\text { No } \\
\mathbf{n}(\%)\end{array}$ & $\begin{array}{c}\text { I am not sure } \\
\mathbf{n}(\%)\end{array}$ \\
\hline $\begin{array}{l}\text { Do you believe in counseling should be given about smoking cessation to the } \\
\text { parents? }\end{array}$ & $78(88.6)$ & $6(6.8)$ & $4(4.6)$ \\
\hline $\begin{array}{l}\text { Do you believe in parental smoking cessation to be useful for the treatment of } \\
\text { chronic cough in children? }\end{array}$ & $88(100)$ & - & - \\
\hline Do you feel qualified about the management of chronic cough in children? & $30(34)$ & $29(33)$ & $29(33)$ \\
\hline Are you aware of international cough guidelines in children? & $50(56.8)$ & $30(34.1)$ & $8(9.1)$ \\
\hline Do you support the development of a national cough guideline? & $85(96.6)$ & $3(3.4)$ & - \\
\hline Do you support sessions about chronic cough in national congresses? & $88(100)$ & - & - \\
\hline
\end{tabular}

The study has clearly shown that pediatricians evaluated children with chronic cough in a considerable amount in their routine practice. However, they felt insufficient about the evaluation and management of chronic cough in children, and most of them expressed of willing to learn more about this topic. The pediatricians obtained some of the required investigations less often (such as spirometry) and more often ordered some others tests (such as total IgE or waters radiography). Also, they often sought consultations from other specialties in the evaluation of chronic cough in children. As a result, frequent number of consultations probably increase the patient population in other specialties and generate a burden on health care system ${ }^{4,6-8}$.

All pediatricians mentioned that they prescribed antibiotics to children in chronic cough management with a preference mainly macrolides. In addition, other broad-spectrum antibiotics were also prescribed with a significant number of percentage. This type of practice might result in increase resistance to antibiotics ${ }^{9}$. The majority of them prescribed cough medications, expectorants and antihistamines in a great amount and two thirds prescribed empiric anti-reflux medications when an etiology could not be defined. The statement in the cough guidelines is clear that children with chronic cough should be etiologically treated ${ }^{6,7}$. Unlike adult data, gastroesophageal reflux disease is not a frequent cause of cough in children6,10. Therefore, empiric anti-reflux medications should not be recommended arbitrarily.

It is well known that exposure to tobacco products cause cough in children 11-14. Most pediatricians did not questioned tobacco exposure in children with chronic cough. Additionally, the great majority of them did not recommend parents professional counseling about smoking cessation. The argument of the participants was mostly about their busy clinical practice and their low rate of beliefs that their attempts would be successful. In general, the pediatricians supported the professional counseling about smoking cessation. The cough guidelines specifically recommend interventional options against tobacco exposure at homes ${ }^{6,7}$. Fortunately, there is law that prohibits smoking in confined areas since 2009 in Turkey ${ }^{15}$. The Ministry of Health has invested a significant budget in 
smoking cessation centers. Behavioral counseling of mothers who smoke has been shown beneficial effect against tobacco exposure to young children ${ }^{16}$.

This study emphasizes that pediatricians have lack of knowledge about the systematic evaluation of chronic cough in children.Cough guidelines provide comprehensive and practical approaches for the management of chronic cough in children ${ }^{6,7}$. Several studies have shown that cough guidelines could be applicable in daily clinical practice ${ }^{17-19}$. It is important for the physicians who deal with chronic cough to implement the guideline recommendations in their clinical practice. Most of the pediatricians stated that they were aware of the cough guidelines published by AACP or BTS. However, they did not know the content of these guidelines.

The present study has also shown that the clinical practice of the participants was variable from each other in terms of the laboratory investigation and prescribed medications. This finding might be partly due to the absence of a national guideline about the management of chronic cough in children.Therefore, the development of national cough guideline would be much useful. The majority of the pediatricians also stated that they supported the development of a national cough guideline in children. A national cough guideline might decrease the differences in personal practices.

More studies with a large sample size are needed to test the reproducibility of our data.

In conclusion, our data is important to emphasize the pediatricians lack of knowledge on chronic cough management. We also found that pediatricians were aware of their lack of knowledge and willing to receive postgraduate education on chronic cough management.A national cough guideline with evidence-based management would be helpful in this manner.
Declaration of Conflicting Interests: The authors declare that they have no conflict of interest.

Financial Disclosure: No financial support was received.

\section{REFERENCES}

1. French CL, Irwin RS, Curley FJ, et al. Impact of chronic cough on quality of life. Arch Intern Med. 1998; 158: 1657-61.

2. Irwin RS, Baumann MH, Bolser DC, et al. Diagnosis and management of cough executive summary: ACCP evidence-based clinical practice guidelines. Chest. 2006; 129 (suppl 1): 1S-23S.

3. Cornford CS, Morgan M, Ridsable L. Why do mothers consult when their children cough? Fam Pract. 1993; 10: 193-6.

4. Marchant JM, Newcombe PA, Juniper EF, et al. What is the burden of chronic cough for families? Chest. 2008; 134: 303-9.

5. Young EC, Smith JA. Quality of life in patients with chronic cough. Ther Adv Respir Dis. 2010; 4: 49-55.

6. Chang $A B$, Glomb WB. Guidelines for evaluating chronic cough in pediatrics: ACCP evidence-based clinical practice guidelines. Chest. 2006; 129: 260-83.

7. Shields MD, Bush A, Everard ML, et al. BTS guidelines: Recommendations for the assessment and management of cough in children. Thorax. 2008; 63 Suppl 3: iii1-iii15.

8. Irwin RS. Introduction to the diagnosis and management of cough: ACCP evidence-based clinical practice guidelines. Chest. 2006; 129: 25S-27S.

9. Roca I, Akova M, Baquero F, et al. The global threat of antimicrobial resistance: science for intervention New Microbes New Infect. 2015; 16: 22-9.

10. D'Urzo A, Jugovic P. Chronic cough. Three most common causes. Can Fam Physician. 2002; 48: 1311-6.

11. Brand PL, Duiverman EJ. Coughing and wheezing children: improvement after parents stop smoking. Ned Tijdschr Geneeskd. 1998; 142: 825-7.

12. Cook DG, Strachan DP. Health effects of passive smoking-10: Summary of effects of parental smoking on the respiratory health of children and implications for research. Thorax. 1999; 54: 357-66.

13. Elliot JG, Carroll NG, James AL, et al. Airway alveolar attachment points and exposure to cigarette smoke in utero. Am J Respir Crit Care Med. 2003; 167: 45-9 
14. Brand PL, Duiverman EJ. Coughing and wheezing children: improvement after parents stop smoking. Ned Tijdschr Geneeskd. 1998; 142: 825-7.

15. T.C. Sağlık Bakanlığı. Havanı koru. Dumansız hava sahası (Republic of Turkey, Ministry of Health. Save your weather. The weather without smoke) Available via Google http://havanikoru.org.tr/yasa-hakkinda/14207-sayili-yasaya-kisaca-goz-atalim.html. Asscessed 4 July 2015.

16. T.C SağlıkBakanlığı. Tütün ve sigarayla mücadele kampanyası (Rebublic of Turkey Ministry of Health. The fight against tobacco and smoking campaign Accessed Available via Google http://www.saglik.gov.tr/SGGM/belge/115738/kampanya-hakkinda.htmlHovell. Accessed 4July 2015.
17. Asilsoy S, Bayram E, Agin $\mathrm{H}$, et al. Evaluation of chronic cough in children. Chest. 2008; 134: 1122-8.

18. Marchant JM, Masters IB, Taylor SM, et al. Evaluation and outcome of young children with chronic cough. Chest. 2006; 129: 1132-41.

19. Usta Guc B, Asilsoy S, Durmaz C. The assessment and management of chronic cough in children according to the British Thoracic Society guidelines: descriptive, prospective, clinical trial. Clin Respir J. 2014; 8: 330-7. 